\title{
Refleksiv praksislæring i virtuelle, transparente læringsmiljøer
}

\section{Monica Irene Krarup Olesen}

Adjunkt, M.Ed.

Undervisning, forskning og udvikling

Act2learn, University College Nordjylland

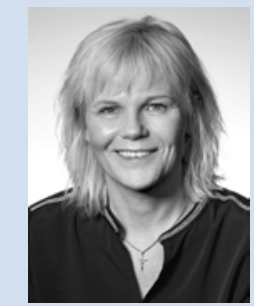




\section{Abstract}

Et undervisningsforløb tilrettelagt som blended learning (BL) inddrog ePortfolier som virtuelt værktøj og omdrejningspunkt for social læring og refleksion. Forløbet dannede afsæt for et forskningsprojekt, der ønskede at identificere de læringsfremmende faktorer, som de oplevedes af de pædagogiske diplomstuderende, og at undersøge, om den læring der fandt sted, kunne defineres som refleksiv praksislæring (RPL). I artiklen argumenteres for, at ePortfolie-metodikken skaber mulighed for transparente læringsmiljøer, og at asynkron og skriftlig kommunikation gennem bundne og praksisrettede refleksionsopgaver fremmer udvikling af professionel identitet og professionskompetencer og lægger således op til RPL og udvikling af selvfaciliteringskompetencer.

Keywords: Virtuelle læringsfællesskaber, refleksiv praksislæring, ePortfolier.

\section{Abstract (engelsk)}

A teaching course organized as blended learning (BL) incorporated ePortfolie as a virtual tool and focal point for social learning and reflection. The course formed the basis for a research project that wanted to identify the factors of learning that were experienced by the pedagogical diploma students and to investigate whether the learning that took place could be defined as Reflective Practice-Based Learning (RPL). The article argues that the ePortfolie methodology allows for transparent learning environments and that asynchronous and written communication through practice-oriented tasks of reflection promotes the development of professional identity and professional competencies, thus addressing RPL and developing self-facilitating skills.

Keywords: Virtual learning communities, Reflective Practice-Based Learning, ePortfolios.

\section{Introduktion}

På University College Nordjylland arbejdes der aktuelt med at indkredse kernen i UCNs tilgang til læring: Refleksiv praksislæring (RPL). Et bidrag til denne proces har været en undersøgelse, der pågik i efteråret 2016 i UCN's efter- og videreuddannelsesafdeling, hvor 11 diplomstuderende deltog i et undervisningsforløb tilrettelagt som blended learning (BL). BL forstås her som et didaktisk begreb for tilrettelæggelse af en undervisning, der kombinerer fysisk tilstedeværelse med virtuel undervisning. Formålet med undersøgelsen var at belyse processerne bag individuel læring initieret af læreprocesser genereret i et virtuelt læringsfællesskab; undersøgelsen søgte dermed svar på, 
hvilke faktorer der opleves som læringsfremmende hos den enkelte studerende, når undervisningsforløbet er tilrettelagt som BL og med ePortfolier som omdrejningspunkt for social læring og refleksion, og om den læring der sker, kan identificeres som RPL.

Undersøgelsen tager afsæt i Grounded Theory, hvor det overordnede mål er at udvikle en empirisk funderet teori, der kan forklare sammenhængene mellem de identificerede læringsfremmende faktorer. Data blev indsamlet via et semistruktureret interview samt løbende, virtuel observation af studieaktiviteten i undervisningsforløbet.

I denne artikel præsenteres baggrunden, undersøgelsen samt resultaterne af undersøgelsen.

\section{Baggrund}

Ifølge EVA-rapporten "E-læring og blended learning på VEU-området" (2011) er der identificeret 72 diplomuddannelser udbudt som BL på landets professionshøjskoler. Da deltagerne på diplomuddannelserne typisk er voksne med mange års erhvervserfaring, der ønsker faglig opdatering og anden kompetenceudvikling i samspil med andre voksne, opfattes BL som en særligt relevant tilrettelæggelsesform. Brug af BL har for denne målgruppe særlig relevans på grund af de særlige behov i målgrupperne, hvor man som voksen ofte har både familie- og arbejdsliv, og hvor fleksibilitet i tilrettelæggelsen af læreprocesserne er helt afgørende for deres deltagelse. Desuden kan mange voksne have meget forskelligartede skoleerfaringer, som ikke nødvendigvis passer sammen med mere traditionelle måder at tilrettelægge uddannelse på (EVA, 2011).

Forskningsmæssigt synes områderne BL/e-læring endnu at være underbelyst. Dette gælder specifikt i forhold til professionsområdets vekseluddannelser, hvor læring forstås som et samspil mellem teori og praksis kombineret med personlige og faglige refleksioner. De fleste videnskabelige undersøgelser relateret til studerendes læringsmuligheder - beskæftiger sig med enten gymnasiale uddannelser eller højere universitetsuddannelser (Graham, 2013, Torrisi \& Drew, 2014), som ikke har tradition for at kombinere teoretisk viden med praktisk viden, som tilfældet er med professionsuddannelserne generelt og professionsuddannelsernes efter- og videreuddannelse specifikt. De generelle undersøgelser af vidensudvikling indenfor BL i gymnasiale og højere uddannelser kan ikke direkte overføres til professionshøjskolernes mere komplekse efter- og videreuddannelsesforløb, hvor didaktik og læring placerer sig i spændingsfeltet mellem teori og praksis. 
Den elektronisk portfolio (ePortfolio) er blevet den foretrukne teknologi til håndtering af livslang læring og karriereudvikling (E-portfolio | Knowledge $\underline{L a b}$ ), hvor de bærende processer er involvering i og refleksion over egen læreproces. Der findes imidlertid flere typer af portfolio, hvor formålet med, og dermed læringsforståelsen bag definerer fokus i portfolien. Formålet kan således være af dokumentarisk (behavioristisk) eller refleksiv (kognitiv) karaktér på den ene side - og af individuel eller social karaktér på den anden side (Dysthe \& Engelsen, 2005; Ellmin, 2001).

Portfoliometodikken i det blendede undervisningsforløb, som er denne artikels genstandsfelt, tager udgangspunkt i ePortfolien som et refleksions- og læringsredskab. Læringsforståelsen i en refleksionsportfolio bygger på kognitiv tænkning, hvor kundskab opfattes som konstrueret, og læring ses som en indre, aktiv konstruktionsproces af tankestrukturer. Læringsportfolio bygger på den antagelse, at læring foregår både som en indre refleksionsproces og i interaktion med omgivelserne (Ellmin, 2001). Formålet er at fremme selvstændig læring og udvikling gennem refleksion over teori og praksis og gennem refleksion over egen læreproces. Kendetegnende for sådanne portfolioer er refleksion og metarefleksion, og indholdet vil typisk være skriftlige refleksioner over teori, praksis og læring (Dysthe \& Engelsen, 2005).

Individuelle refleksioner og læringsstrategier finder altid sted i og i relation til en social kontekst. Dyste (2003: 48) taler om, hvordan læring fra sociokulturelle positioner "[..] lægger afgørende vægt på, at kundskab bliver konstrueret gennem interaktion og i en kontekst og ikke primært gennem individuelle processer. Derfor bliver interaktion og samarbejde anskuet som helt grundlæggende for læring og ikke kun som et positivt element i læringsmiljøet". En portfolio bør derfor have til hensigt at fremme interpersonelle læreprocesser mellem de lærende (Dysthe \& Engelsen, 2005).

Denne artikels erkendelsesteoretiske forståelsesgrundlag vil tage udgangspunkt i Dysthes forståelse af et sociokulturelt læringsperspektiv, hvormed anlægges et konstruktivistisk syn på læring forstået på den måde, at den studerende både ses som konstruktør af egen læring, samtidig med at læring ses som en proces, der konstrueres gennem social interaktion i konkrete kontekster (Dysthe, 2003).

Læringstilgangen på University College Nordjylland, RPL, lægger sig på linje med en sociokulturel tilgang til læring, idet antagelsen her er, at den individuelle konstruktion af læring sker i samspil med omverdenen samt koblingen til praksis (Pjengaard, 2016: 2-9). I samme artikelsamling udfolder Pjengaard begrebet RPL således: 
"Refleksiv praksislæring er læring i og af praksissituationer, der stiller krav til deltagerne om en integrativ tankegang, der involverer refleksiv flerperspektivitet eller skiftende refleksive positioner. Den lærende får derigennem øje på sin egen og andres analytiske nuanceringer og differentieringer i forståelsen af praksis. Refleksiv praksislæring er en samlebetegnelse, som er til stede, når praksis belyses, beskrives og forstås gennem en eller flere systematiske teoretiske optikker, og når teorier sammentænkes og forædles gennem indsigter i praksis" (Pjengaard, 2016:34).

I ovenstående definition på RPL læner Pjengaard sig op ad Jack Mezirows indkredsning af transformativ læring, og pointerer, at målet for både transformativ læring og RPL er, at personen gennem refleksion gør sig bevidst om de antagelser, der ligger til grund for egne handlinger, og at personen dels kan handle på baggrund af denne bevidsthed, og dels kan opnå en højere forståelse af sig selv og sin omverden. Den transformative læring involverer derfor kritisk refleksion og villighed til redefinering af problemløsninger; dvs. at den lærende retter sig mod fremtiden og åbner for nye, reflekterede handlinger i praksis (Mezirow, 2000 In: Pjengaard, 2016:19). Ifølge Pjengaard (2016:20) er RPL en overbygning til transformativ læring, eftersom det med RPL er muligt at observere, beskrive, forklare og forstå transformative læringsprocesser og forholde sig vurderende og kritisk til disse.

Kernen i RPL er samspillet mellem teori og praksis kombineret med personlige refleksioner, og det er i dette spændingsfelt, at udviklingen af professionel identitet og professionskompetencer understøttes, idet professionalitet $\mathrm{i}$ handlinger og kommunikation er, hvor den professionelle anvender sin teoretiske viden til at løse problemer i praksis.

Den overordnede hensigt med RPL er at gøre UCN's dimittender parate til fremtidens arbejdsmarked - uanset om man dimitterer fra en grunduddannelse eller fra en efter- og videreuddannelse. RPL er dermed også en didaktisk rammesætning, der skal være med til at sikre, at de studerende tilegner sig ny viden, færdigheder og kompetencer, der kontinuerligt kan kvalificere og udvikle praksis.

Operationaliseringen af RPL tager i denne undersøgelse udgangspunkt i ovennævnte definition og beskrivelse af RPL. På https://www.ucn.dk/omucn/organisation/organisation/læringstilgang er der desuden opsat en række mål for, hvilke færdigheder og kompetencer studerende ved UCN alene og sammen med andre skal tilegne sig for at blive parate til fremtidens arbejdsmarked; målene er derfor operationalisérbare ift. RPL. Med udgangspunkt i disse mål samt Pjengaards (2016) definition ovenfor vil nedenstående læringsmål blive anvendt i et forsøg på at identificere RPL i den senere analyse. 
Der kan identificeres tegn på RPL som følge af, at den studerende:

- opstiller hypoteser og afprøver idéer i praksis på baggrund af kritisk refleksion.

- kommer med løsninger på problemstillinger og argumenterer for bestemte handlemåder.

- anvender effektive læringsstrategier til løsningen af opgaver i praksis som følge af øget teoretisk indsigt og forståelse for det, der arbejdes med.

- retter sig mod fremtiden og åbner for nye, reflekterede handlinger i praksis.

- forholder sig vurderende og kritisk til tidligere og nuværende måder at lære på.

På baggrund af ovenstående forståelsesgrundlag er der i denne undersøgelse valgt en kvalitativ metode. Den kvalitative metode er valgt, da undersøgelsens centrale spørgsmål omhandler erfaringer, oplevelser og holdninger hos undersøgelsens informanter. For at kunne udforske hvad de diplomstuderende tillægger særlig betydning indenfor undersøgelsens kontekst vurderes metodologien Grounded Theory, med dens symbolske interaktionistiske perspektiv, at være en relevant forskningstilgang. Fokus er her netop at undersøge og forklare sociale processer og forhold, som tillægges betydning for den gruppe mennesker, der deltager i undersøgelsen (Glaser \& Strauss 1967).

Nedenfor følger en litteraturgennemgang, der belyser temaerne "gennemsigtighed i ePortfolier" og "IT-baserede læreprocesser". Litteraturgennemgangen er foretaget i forbindelse med undersøgelsen og har til hensigt at afeller bekræfte de didaktiske formodninger og overvejelser, der ligger til grund for undervisningsforløbet i forhold til, hvad der kan fremme læring i transparente, virtuelle læringsmiljøer. Derefter udfoldes undersøgelsens metode, hvorefter resultaterne præsenteres, analyseres og diskuteres. I analysen inddrages såvel individfokuserede læringsteorier (Jack Mezirow og Mads Hermansen) som sociale diskursfokuserede læringsteorier (Etienne Wenger og Peter Jarvis).

\section{Litteraturgennemgang}

\section{ePortfolier og gennemsigtighed}

En undersøgelse af Jones m.fl. (2015) viste, at opmærksomhed på medstuderendes ePortfolier, gennem øget gennemsigtighed og peer-feedback havde en positiv effekt. De studerende havde forbedret deres teknologiske kompetencer gennem brug af disse i designet, ligesom de gennem studiet også forbedrede deres refleksions- og selvevalueringskompetencer. En afgørende komponent i ePortfolio-designet af Jones m.fl. var gennemsigtigheden, dvs. at de 
studerende til enhver tid kunne se hinandens opgavebesvarelser samt underviserens feedback på disse besvarelser.

Ifølge Bollinger \& Shepherd (2010) bliver studerende bedre til at se, hvordan de kan forbedre egne studieprodukter, når de har adgang til at se fx medstuderendes produkter, hvilket ifølge Lowenthal og Thomas (2010) kan forklares med, at gennemsigtighed (transparency) svarer til musikeres og kunstneres optrædener foran et interesseret publikum; man gør sig umage og forsøger at yde sit absolut bedste, når man skal vurderes af andre.

Gennemsigtighed som metode understøttes af teorier om Cooperative Learning (CL) (Dalsgaard \& Paulsen, 2009). Et af de væsentligste elementer i CL er netop, at elever bliver (gjort) opmærksomme på den viden og de færdigheder, som de øvrige i læringsrummet besidder med henblik på at udlede læring deraf. Gennemsigtighed forstås af Dalsgaard \& Paulsen (2009) som studerendes og lærernes indsigt i hinandens aktiviteter og ressourcer, og hensigten med gennemsigtighed er, at studerende og undervisere bliver opmærksomme på - og har adgang til - hinandens refleksioner, interesser og opgaver; dvs. deltagerne står til rådighed for hinanden som ressourcer for deres læringsaktiviteter.

Gennemsigtighed er et dominerende træk ved personlige læringsmiljøer (Dalsgaard, 2011). I personlige læringsmiljøer vælger og organiserer studerende selv værktøjer og har kontrol over deres læringsaktiviteter (Dalsgaard, 2006 in: Dalsgaard, 2011). Det personlige læringsmiljø kan dermed indbefatte værktøjer og tjenester fra uddannelsesinstitutionen, som $\mathrm{fx}$ læringsplatformen Canvas og ePortfolier.

Ifølge en sociokulturel tilgang er viden bundet til sociokulturelle praksisser, hvori individer udfører handlinger. Læringen finder sted i individets udførelse af individuelle handlinger i en kollektiv praksis. Konsekvensen er ikke nødvendigvis, at individer skal samarbejde, men det er centralt, at man har indblik i relaterede aktiviteter i sin praksis. Det vil sige, at der i et læringsmiljø bør være gennemsigtighed mellem de studerende. I dette perspektiv er viden de redskaber (tekster, begreber, teorier, osv), som individet anvender til at udføre handlinger med. Udgangspunktet er individets selvstændige arbejde og selvstyrede aktiviteter. Det er dog essentielt at understøtte sociale relationer i form af kommunikation, dialog, samarbejde og ikke mindst gennemsigtighed (Dalsgaard, 2011). Ifølge Dalsgaard (2011) bør studerende desuden - i elæringssammenhænge - få mulighed for at sammensætte digitale /virtuelle værktøjer ud fra deres behov og aktuelle aktiviteter: Viden er redskaber, som den studerende anvender i læringsaktiviteter, hvorfor også internettet er at betragte som redskaber for den studerendes aktiviteter. 


\section{IT-baserede læreprocesser - muligheder og begrænsninger}

Den manglende fysiske tilstedeværelse har stor betydning for IT-baseret læring, idet den meningsfylde i det faglige indhold der kan formidles i situationer baseret på kropslig tilstedeværelse, muliggør etableringen af en fælles baggrundsforståelse af faglig-social-personlig art, og denne resonerer med i de ord, der siges, således at disse får et dybere og mere mangefacetteret fagligt-socialt-personligt indhold for de mennesker, der deltager i den pågældende sammenhæng, end ordene har "i sig selv", betragtet uden for denne undervisningssammenhæng (Dohn, 2007). Omvendt kan den fagligtsociale-personlige meningshelhed bevirke, at deltagere i en undervisningssituation bliver for indforståede med risiko for "blinde pletter" i deres synsvinkel, ligesom de personligt-sociale aspekter af meningshelheden kan forårsage negative forhåndsopfattelser blandt deltagerne.

I det virtuelle læringsrum har man kun talte eller skrevne ord at forholde sig til, hvilket eliminerer forstyrrende baggrundsforståelse. Ofte opleves en større social lighed i virtuelle rum, idet dette giver andre og større muligheder for at "komme til orde" for dem, der normalt holder sig tilbage i ansigt-til-ansigtsituationer (især i det asynkrone, skriftlige medie). Denne direkte forholden sig til ordene giver mulighed for at benytte især asynkron skriftlig kommunikation som refleksionsrum: Koncentrationen om ordene, sammenholdt med den længere tid, man har til sin rådighed i det asynkrone medie, giver en refleksionsmulighed, som ikke haves i samme grad i ansigt-til-ansigtsammenhængen med dens hurtigere dialog- og undervisningsform (Dau, 2015). Refleksionen finder i det virtuelle sted i et forum, der stadig er fælles for alle holddeltagere, og hvor asynkroniciteten ikke nødvendigvis er større, end at der kan komme megen respons på en dag. Der muliggøres derfor en dialog, der godt nok ikke er dynamisk som ansigt-til-ansigt-situationen, men som stadig er hurtig nok til, at det er en dialog.

At deltage i et virtuelt læringsrum sammen med fx medstuderende, man kender, vil bevirke, at kendskabet "taler med" i den skriftlige kommunikation; er der etableret en baggrundsforståelse, vil de læste/hørte ord kunne få større meningsmæssig fylde, end de ellers ville have haft. Den optimale IT-baserede læringskommunikation finder sted mellem mennesker, der på andre tidspunkter deltager fysisk i læringssammenhænge, idet de vanskeligheder der er identificeret i relation til e-læring knytter sig til utilstrækkelig etablering af faglig-social-personlig baggrundsforståelse deltagerne imellem. De vanskeligheder der er identificeret er 1) en følelse af isolation, især ved manglende respons fra øvrige diskussionsdeltagere, 2) at skriftlig kommunikation kan virke hæmmende på grund af dens permanente form, og 3) at ITmediet opleves uforpligtende og at det derfor ikke har betydning, om man deltager (Dohn, 2007; Dau, 2015). Virtuelle læringsrum kan bidrage med 
refleksions- og koncentrationsmuligheder og dermed læringsmuligheder, der ikke gives ansigt til ansigt. Det forudsætter dog, at de optræder som integrerede dele af et undervisningsforløb, hvori der i væsentlig grad også indgår ansigt-til-ansigt-undervisning.

Ved asynkron kommunikation bidrager de studerende med individuelle skriftlige indlæg, og gennem kommunikation med medstuderende skabes en fælles faglig forståelse (Sorenson, 2000). Den asynkrone kommunikation har potentiale, idet den er permanent, således at de studerende kan genlæse indholdet og anvende det i en senere sammenhæng. Det asynkrone læringsmiljø fremhæves som en metode, der understøtter refleksion og faglig fordybelse. Skriveprocesser understøtter i sig selv den enkelte studerendes faglige forståelse og læringsudbytte. Det at skulle udtrykke faglighed med egne ord tydeliggør for den studerende, hvad der ikke er forstået (Dysthe \& Engelsen, 2005).

\section{Formål}

Formålet med undersøgelsen var at undersøge, hvilke faktorer der opleves som læringsfremmende hos den enkelte studerende, når undervisningsforløbet er tilrettelagt som BL og med ePortfolier som omdrejningspunkt for social læring og refleksion, og om den læring der sker, kan identificeres som refleksiv praksislæring.

Det overordnede formål var, på baggrund af denne undersøgelse, at udvikle en generel, faktisk procesteori (Glaser \& Strauss, 1967; Hartman, 2005), der illustrerer en processuel sammenhæng mellem de identificerede læringsfremmende faktorer. Hensigten er at anvende en sådan procesteori som didaktisk rammesætning i fremtidige undervisningsforløb på de pædagogiske diplomuddannelser, der tilrettelægges som BL; herunder en didaktisk rammesætning der i væsentlig grad afspejler tankerne bag refleksiv praksislæring.

\section{Metode}

Undersøgelsens metode læner sig op ad Grounded Theory, hvor kategorier, egenskaber og sammenhænge mellem disse fremvaskes af empirien, men hvor forskningsspørgsmålet er stillet på forhånd, som beskrevet af Strauss og Corbin (1998), idet intentionen I denne undersøgelse ikke var at tage udgangspunkt $\mathrm{i}$ en gruppe menneskers problemstilling, men at få indsigt $\mathrm{i}$ samt afdække læringsfremmede faktorer i virtuelle, transparente læringsmiljøer. 
Grounded theory bygger på den symbolske interaktionismes teori om, at tilværelsen skabes og ændres gennem interaktionen mellem mennesker. Udgangspunktet er, at vores adfærd kommer til udtryk i en given kontekst og derfor ikke kan forstås uden for denne. Menneskelig adfærd må derfor nødvendigvis iagttages i naturlige situationer.

Grounded Theory er anvendelig, når man behandler åbne problemstillinger, som fx hvad der sker i en given interaktion, men også til undersøgelse af specifikke problemer, fx hvad informanten tænker om en særlig problemstilling. Grounded Theory placeres ifølge Strauss \& Corbin (1998) indenfor det konstruktivistiske paradigme, der ser virkeligheden som konstrueret, og dermed ses forskeren også som værende fortolkende. Udgangspunktet i denne undersøgelse er derfor, at viden skabes dels i interaktionen mellem forsker og informant og dels i forskerens interaktion med data. Den viden der skabes er derfor ikke sandheder, men blot én af mange mulige udlægninger, der gerne skal bidrage til en større forståelse af forskningsfeltet.

\section{Undersøgelsens genstandsfelt}

FVU (forberedende voksenundervisning) er et tilbud til voksne, der ønsker at forbedre deres færdigheder i læsning, skrivning, stavning og matematik. FVU foregår på voksenuddannelsescentre (VUC) og voksenuddannelsesinstitutioner som for eksempel: aftenskoler, sprogskoler, erhvervsskoler og daghøjskoler. For at kunne varetage undervisning i FVU-læsning (herunder skrivning og stavning) skal underviseren have bestået to fagmoduler i den pædagogiske diplomuddannelse (PD).

De 11 informanter i denne undersøgelse var i efteråret 2016 studerende på det ene af de to obligatoriske fagmoduler (FVU-læsning). . De 11 informanter bestod af 10 kvinder og én mand i alderen 26 til 53 år. Alle informanter blev den første mødegang informeret mundtligt og skriftligt om undersøgelsens formål og design, og alle afgav samme dag samtykke til, at indhentede data kan anvendes i undersøgelsen. Informanterne vil herefter blive refereret til som "PD-studerende"

Fagmodulet FVU-læsning, der er normeret til 10 ECTS, er designet som blended learning med to fysiske fremmødegange, to webinarer, en workshop og en gruppevejledning. Målgruppen på disse moduler er erfarne undervisere fra en FVU-praksis med en uddannelsesmæssig baggrund i form af en professionsbachelor som lærer. Erfaring viser, at denne målgruppe ofte har nogle særlige læringsudfordringer som følge af:

- begrænsede (fysiske) undervisningsgange; de fleste arbejder fuld tid sideløbende med studiet og vælger derfor ofte blended learning pga. studiets tidsmæssige (og geografiske) fleksibilitet. 
- begrænsede refleksionskompetencer som følge af en dyb forankring i praksis (vanens magt).

I forsøg på at undgå at teknologiens begrænsninger og/eller besværligheder skulle hindre læring, blev der til formålet udviklet ePortfolier med minimalistisk funktionalitet og udseende. Således kan man kun 1) oprette/slette brugere, 2) uploade/downloade/slette brugerspecifikke filer og 3) Tilføje refleksioner. Strukturen er fælles, og man kan frit læse/skrive under en vilkårlig bruger.

\section{Undervisningsforløbet}

Pensum på det pædagogiske diplommodul "Skriftsprogsundervisning for voksne - FVU" (10 ECTS) svarer til ca. 1000 siders litteratur. Modulets læringsmål lægger op til en opdeling af pensum i tre temaer, 1) trinplacering af FVU-kursister, 2) didaktik, læring og metoder i FVU og 3) undervisningsplanlægning. Til hvert tema var der knyttet 2-3 konkrete opgaver; herunder refleksion over teori og praksis. Fx bestod den første opgave i, at de studerende skulle formulere egne læringsmål for forløbet. Den anden opgave bestod $i$, at der skulle findes og beskrives en case-kursist, som senere skulle trinplaceres og designes undervisning til. Alle opgaver samt refleksioner over opgaver og temaer skulle uploades i ePortfolierne. Alle studerende og undervisere havde adgang til alles ePortfolier under hele forløbet. Ifølge studieordningen for modulet er det ikke muligt at stille krav om aflevering af opgaveløsninger, men studieplanen for modulet lagde op til, at det var en del af designet, og at der var en forventning om, at opgaverne blev løst og uploadet.

\section{Dataindsamling}

I efteråret 2016 indhentedes datamateriale ved hjælp af et semi-struktureret fokusgruppeinterview samt ugentlige observationer af brugen af ePortfolierne specifikt og den virtuelle studieaktivitet generelt.

Dataindsamling og analyse foregik sideløbende gennem hele forskningsprocessen, hvor der blev nedskrevet teoretiske noter, dvs. tekst med teoretiske spørgsmål, hypoteser, sammenfatning af koder osv. Sideløbende med denne proces blev der foretaget åbne kodninger af observationerne. Hvor kodningen begrebsmæssigt beskriver det, der sker i datamaterialet, er de teoretiske noter mere abstrakte tanker og refleksioner over disse koder.

De fremanalyserede kategorier dannede udgangspunkt for interviewguiden til det afsluttende, semi-strukturede fokusgruppeinterview (tabel 1), hvorigennem vi søgte at få de observerede kategorier mættet og/eller uddybet. Fokusgruppeinterviewet gav ligeledes mulighed for, at der opstod nye kategorier. De virtuelle, deltagende observationer havde fokus på forsknings- 
spørgsmålet; dvs. hvilke læringsfremmende faktorer kan der identificeres hos den enkelte studerende, når undervisningsforløbet er tilrettelagt med ePortfolier som omdrejningspunkt for social læring og refleksion - og kan den læring, der sker, identificeres som RPL?

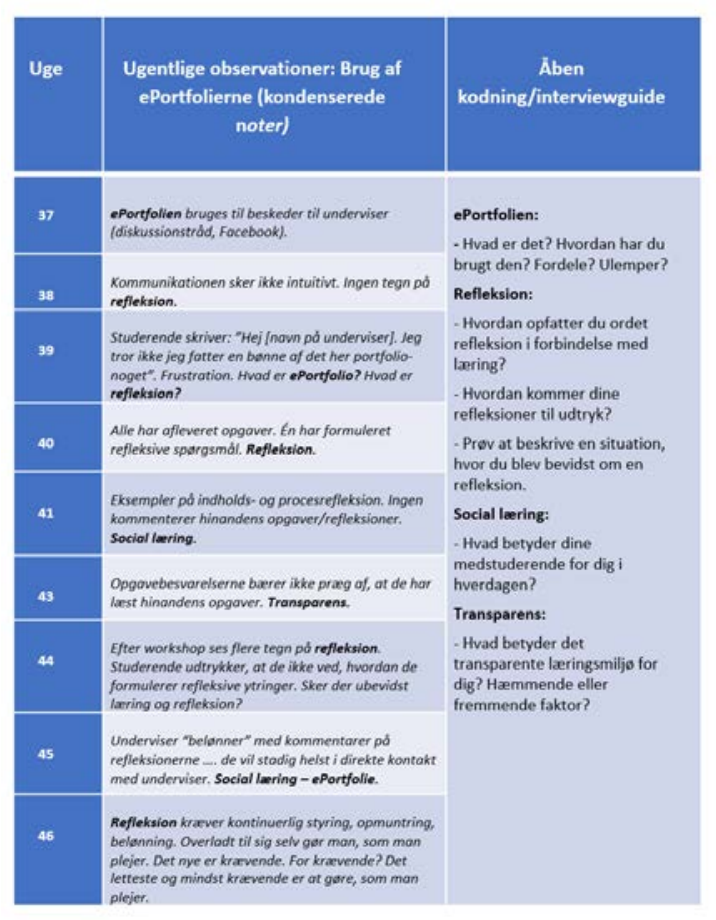

Tabel 1. Åben kodning af ugentlige observationer af brug af ePortfolierne som udgangspunkt for interviewguiden.

\section{Semi-struktureret fokusgruppeinterview}

Der blev udført et semi-struktureret fokusgruppeinterview umiddelbart efter FVU-diplommodulets sidste undervisningsgang (uge 46/2016). Alle 11 studerende deltog i interviewet, der varede 40 minutter. Interviewet blev gennemført ud fra en interviewguide (tabel 1), der var struktureret på baggrund af begreber fra de virtuelle observationer. Interviewet skulle give de studerende mulighed for at beskrive deres oplevelse af undervisningsforløbet for derigennem at uddybe de virtuelle observationer/begreber med henblik på mætning. Interviewet blev optaget digitalt og transskriberet ordret.

Da formålet var at undersøge, hvad de diplomstuderende oplevede som læringsfremmende i undervisningsforløbet, var det relevant at indsamle data via det kvalitative fokusgruppeinterview. Fokusgruppeinterviewets styrke er den interaktion og dynamik, der foregår mellem deltagerne, bl.a. fordi deltagerne spørger ind til hinandens udtalelser og kommenterer hinandens erfaringer og forståelser ud fra en kontekstuel forforståelse, man ikke nødvendigvis har som interviewer. Ved kun at anvende få forberedte interview- 
spørgsmål (tabel 1) blev det muligt at praktisere en fleksibel interviewform. Interviewerne kunne med denne form forfølge de fænomener, som de studerende var særligt optaget af, hvilket er i tråd med Grounded Theory.

Da projektansvarlig for denne undersøgelse også var underviser på FVUmodulet, blev fokusgruppeinterviewet gennemført af de to øvrige projektdeltagere, der ikke havde undervist på modulet og derfor ikke kendte de studerende. Projektansvarlig/underviser var dog til stede under interviewet, hvilket kan have haft indflydelse på resultaterne; det kunne på den ene side skabe tryghed for de studerende, at deres underviser var til stede, men kendskabet kan på den anden side gøre, at man ikke får givet udtryk for fx kritiske faktorer i forbindelse med undervisningsforløbet.

\section{Dataanalyse}

Data fra de løbende, virtuelle observationer blev kodet og anvendt i fokusgruppeinterviewet, som beskrevet ovenfor. Denne proces har formodentlig bidraget til mætning af de fremanalyserede begreber. Dette afsnit beskriver den videre analyseproces og fungerer derfor også som læseanvisning til tabel 2 og 3 (side 17-18). Eksempler fra tabellerne inddrages undervejs.

Data fra fokusgruppeinterviewet blev analyseret linje for linje, hvor hver linje/hvert citat blev kondenseret til et emne/tema. Et eksempel på en sådan kondensering ses i tabel 2, hvor følgende citat kodes: "Der tænker jeg så, at på samme måde kan det jo faktisk også være betryggende at - ok jeg har forstået det på den her måde, og så skriver Monica (underviser), at nej, det er helt hen i vejret, ikke også - og så tænker man, ok, det er nok ikke helt rigtigt læst eller omvendt, ikke også - så får man faktisk bekræftet, at ok, jeg har faktisk forstået det her". Dette citat blev tildelt temaet "Det er trygt, når underviser afeller bekræfter forståelsen".

Gennem linje for linje-kodning og analyse af citaterne opstod mønstre og nye temaer. Tre temaer kunne samles under kategorien "Anerkendelse og feedback";

1. Korrespondance mellem underviser og studerende/stilladsering.

2. Det er trygt, når underviser af- eller bekræfter forståelsen.

3. (Skriftlige) refleksioner har kun værdi, hvis de anerkendes (af underviser).

En kategori er et fænomen, som har en bestemt mening for en gruppe mennesker, og blandt kategorierne er der én kernekategori, som kendetegnes ved, at den er mere kompleks og kan samle de andre kategorier. Kernekategorien indfanger det, som muligvis ligger bag de øvrige kategorier; dét som de øvrige kategorier kan relateres til. Kernekategorien er "Udvikling af 
selvfaciliteringskompetencer". Kernekategorien er valgt, da den indkapsler de læringsfremmende faktorer, som denne undersøgelse har forsøgt at identificere. Læringsfremmende faktorer i et undervisningsforløb tilrettelagt som blended learning kommer i høj grad til at handle om "at tage sig selv i uddannelse"; dvs. kontinuerligt at kunne facilitere sin læring på egen hånd i langt højere grad end i et traditionelt undervisningsforløb. Kernekategorien samt relationer mellem denne og de øvrige kategorier vil blive uddybet i de kommende afsnit.

I den selektive kodning blev de temaer, der var relevante for kernekategorien, udvalgt. Alle tre ovennævnte temaer indgår og samles til en note: "I virtuelle læringsmiljøer har man især behov for at blive set og hørt og få at vide, om man er på rette vej”. I større undersøgelser med en meget større mængde data, ville man her selektere i fremanalyserede temaer.

Efter mætning af kategorierne kunne en teoretisk kodning begynde. Teoretisk kodning benyttes til at organisere relationen mellem kernekategorien og relaterede kategorier og viser, hvordan de er relateret til hinanden. De teoretiske koder, der blev fundet gennem analysen, har til hensigt at binde teorien sammen. Kategorien "Anerkendelse og feedback" relaterer sig til kernekategorien med den teoretiske note: "Engagement og motivation for fortsat og dybere læring fordrer anerkendelse og feedback". Det er således afgørende - i undervisningsforløb tilrettelagt som blended learning - at modtage hyppig og vedvarende anerkendelse og feedback, hvis motivation og engagement for fortsat udvikling af selvfaciliteringskompetencer skal bevares.

\section{Resultater}

De fremanalyserede kategorier samt kernekategorien er udforsket på baggrund af forskningspørgsmålet "hvilke faktorer opleves som læringsfremmende hos den enkelte studerende, når undervisningsforløbet er tilrettelagt som BL og med ePortfolier som omdrejningspunkt for social læring og refleksion, og kan den læring der sker, identificeres som refleksiv praksislæring"? I dette afsnit bliver resultaterne kort præsenteret, hvorefter følger en analyse af resultaterne.

Det overordnede formål med denne undersøgelse var at udvikle en generel, faktisk procesteori (Glaser \& Strauss, 1967; Hartmann, 2005), der illustrerer en processuel sammenhæng mellem de identificerede læringsfremmende faktorer. På baggrund af undersøgelsens resultater præsenteres procesteorien nedenfor (figur 1). Procesteorien består af kernekategorien "udvikling af selvfaciliteringskompetencer" samt af kategorierne "Forstyrrelse", "Anerkendelse og feedback", "Praksisrefleksion" og "Aktiv/passiv deltagelse". 


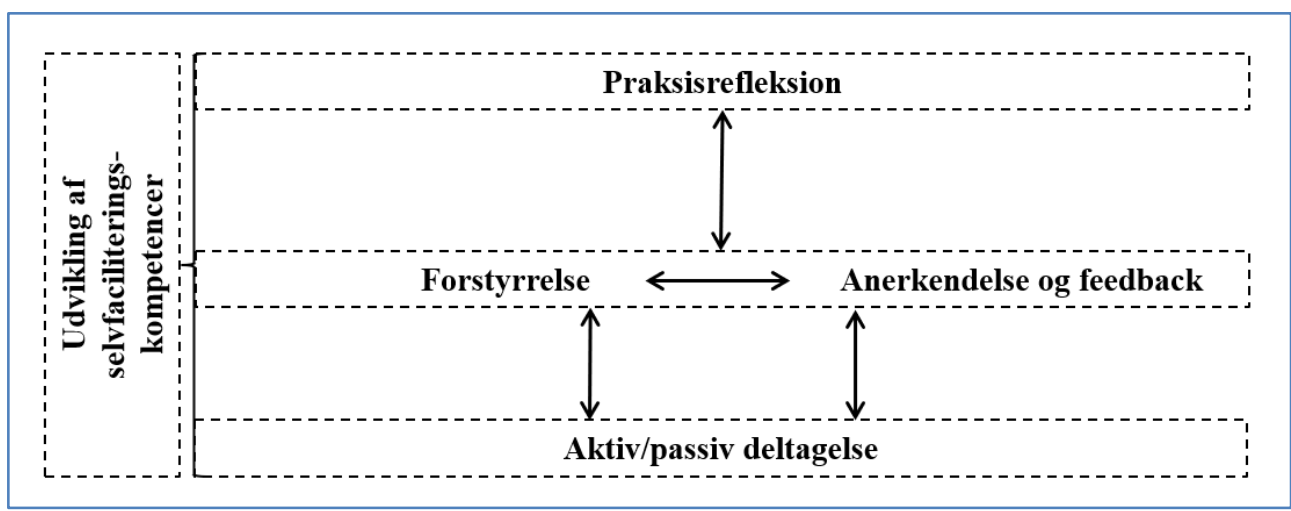

Figur 1. Procesteorien med udgangspunkt i kernekategorien "Udvikling af selvfaciliteringskompetencer.

Kernekategorien "udvikling af selvfaciliteringskompetencer" trådte frem af analysen som den form for læring, der kan blive resultatet af at deltage i et læringsforløb, hvor man primært oplever designet som motiverende og læringsfremmende, og hvor man samtidigt anerkender nødvendigheden af refleksion og læring. Selvfaciliteringskompetencer vil i denne undersøgelse sige, at den diplomstuderende aktivt deltager i egen læreproces; dvs. at læringen initieres, kontrolleres og styres af den studerende i en iterativ proces. Denne proces er foregået i et dynamisk og fleksibelt samspil i et transparent og virtuelt læringsmiljø, hvorfra den studerende har hentet inspiration, forstyrrelser og nuanceringer til brug i sit individuelle kritiske refleksionsarbejde.

De fremanalyserede kategorier angiver hvilke læringsfremmende faktorer, der er identificeret i læringsforløbet tilrettelagt som blended learning og knytter sig til kernekategorien på baggrund af følgende resultater:

- Praksisrefleksion: Konkrete, praksisrettede opgaver tydeliggjorde refleksionens genstand og faciliterede kritisk refleksion.

- Forstyrrelse: Krav om at alle opgavebesvarelser skulle afleveres ePortfolierne skabte mulighed for at hente forstyrrelser og inspiration i et virtuelt, transparent, læringsrum.

- Anerkendelse og feedback: Hyppig, skriftlig og anerkendende respons på alle opgaver er afgørende for motivation, refleksion og læring.

- Aktiv/passiv deltagelse: Alle former for deltagelse i et virtuelt, transparent læringsmiljø skaber mulighed for at hente inspiration, forstyrrelser og nuanceringer. Dette asynkrone læringsrum med overvejende brug af skriftlig (og dermed permanent) kommunikation skaber mulighed for refleksion og faglig fordybelse. 
Konklusionen i denne undersøgelse er, at de tegn på læring, der er identificeret, placerer sig i sociale, praksisrettede og refleksive læringsdimensioner og dermed kan være tegn på RPL. I forhold til operationaliseringen af RPL (side 4-5) er datamaterialet i denne undersøgelse for begrænset til at kunne af- eller bekræfte samtlige forhold. Resultaterne peger dog på, at de PDstuderende på FVU-modulet opnåede følgende opsatte mål for RPL og bekræfter dermed, at der i denne undersøgelse er identificeret tegn på RPL:

- De opstillede hypoteser og afprøvede ideer i praksis på baggrund af kritisk refleksion.

- De opnåede øget teoretisk indsigt og forståelse for deres opgaver i praksis.

- De rettede sig mod fremtiden og åbnede for nye, reflekterede handlinger i praksis.

- De forholdt sig vurderende og kritisk til tidligere og nuværende måder at lære på.

Tabellerne 2 og 3 nedenfor viser analyse- og kodningsprocesserne. Tabellerne læses vandret og illustrerer processen, hvor data fra fokusgruppeinterviewet kondenseres til et emne/tema. Kernekategorien er placeret i tredje kolonne med henblik på at indfange dét, som de øvrige kategorier kan relateres til. I den selektive kodning er de for kernekategorien relevante temaer udvalgt, hvorefter den teoretiske kodning præsenteres. Den teoretisk kodning organiserer relationen mellem kernekategorien og de relaterede kategorier, som præsenteres i den sidste kolonne. 


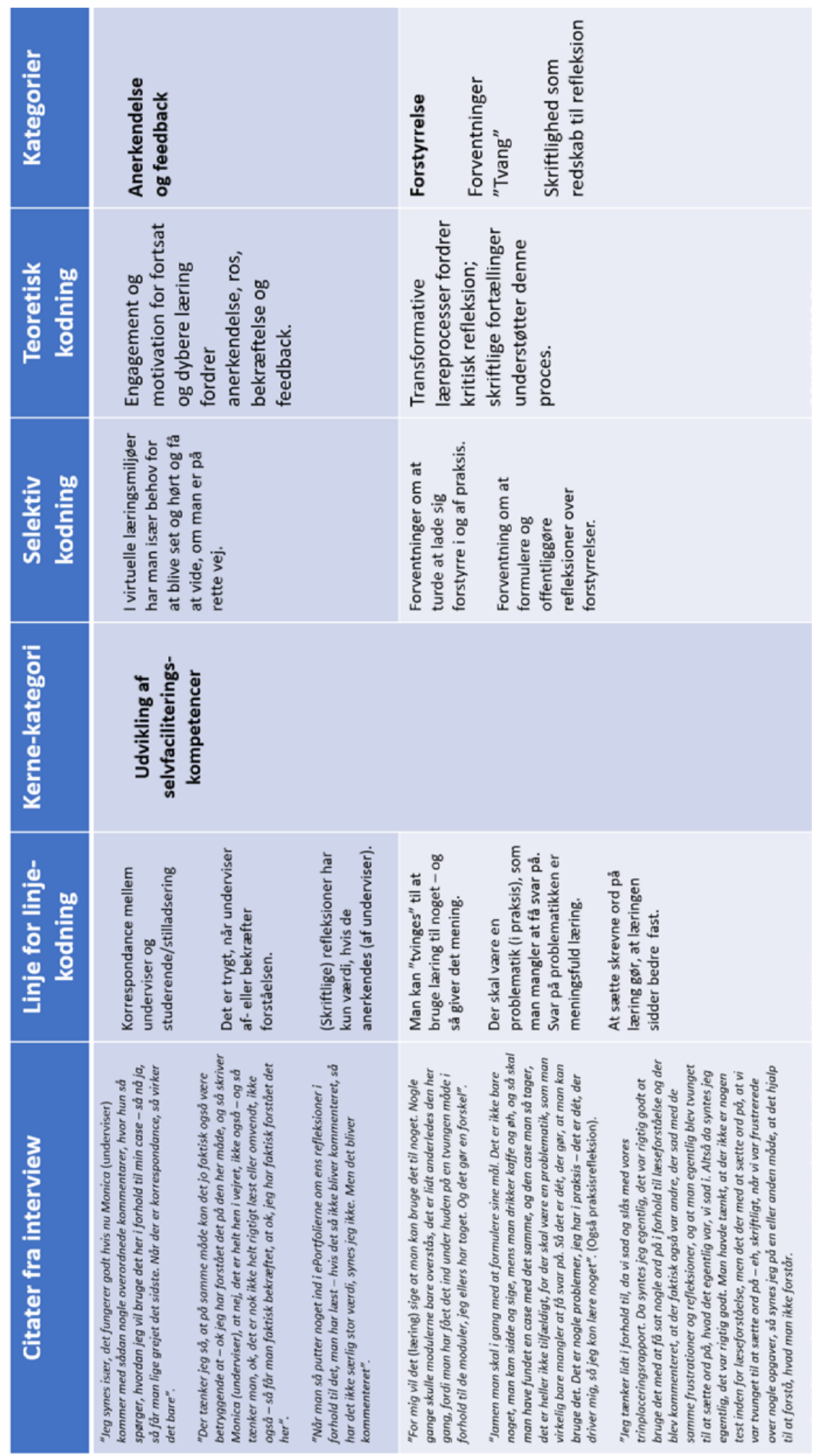

Tabel 2. Analyse- og kodningsproces i kategorierne anerkendelse og forstyrrelse. 


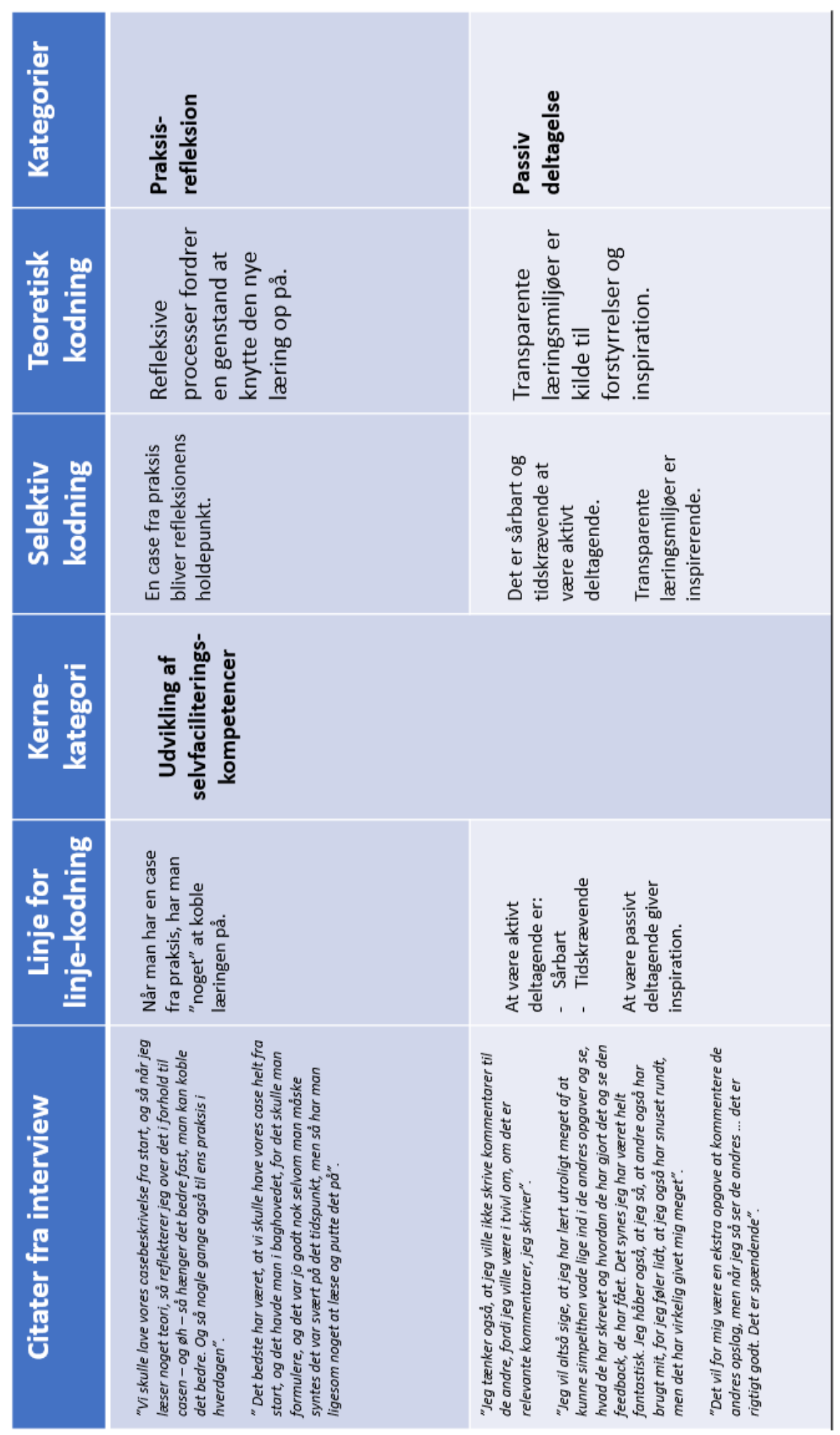

Tabel 3. Analyse- og kodningsproces i kategorierne praksisrefleksion og passiv deltagelse. 


\section{Praksisrefleksion}

Refleksionsopgave nr. 2 i undervisningsforløbet bestod i, at de studerende skulle finde og beskrive hver deres case-kursist; dvs. en person "fra virkeligheden", som først skulle beskrives. I senere opgaver skulle casepersonen testes og trinplaceres, ligesom der skulle designes et undervisningsforløb til case-kursisten. Nogle informanter fremhæver casens centrale rolle som særlig udbytterig i forhold til at koble teori med praksis, og dermed fremstår refleksionsopgaven, der kobler case og teori, som en læringsfremmende faktor:

\section{- Vi skulle lave vores casebeskrivelse fra start, og så når jeg læser noget teori, så reflekterer jeg over det i forhold til casen - og øh- så hænger det bedre fast, man kan koble det bedre. Og så nogle gange også til ens praksis i hverdagen.}

- og den case man så tager, det er heller ikke tilfældigt, for der skal være en problematik, som man virkelig bare mangler at få svar på. Så det er dét, der gør, at man kan bruge det. Det er nogle problemer, jeg har i praksis - det er dét, der driver mig, så jeg kan lære noget.

Refleksionsopgaverne, der koblede case og teori, var omdrejningspunktet i undervisningsforløbet, og derfor var det afgørende, at alle opgavebesvarelser samt feedback på og diskussion af opgavebesvarelser blev delt i det transparente uddannelsesfællesskab, dvs. i ePortfolierne, til inspiration for alle. Skriftlige ePortfolio-opgavebesvarelser gav imidlertid ikke bare anledning til at stille kritiske spørgsmål til daglig praksis, som citaterne ovenfor indikerer og dermed sikre gældende kvalitet i praksis. Opgaverne sigtede også mod, at kritisk refleksion kunne blive en del af den daglige praksis, således at den vedvarende modtagelighed for fornyelser kunne sikres. Det første citat ovenfor peger på, at der kan være sket en ændring i den måde, den studerende sædvanligvis reflekterer over praksis på: "når jeg læser noget teori, så reflekterer jeg over det i forhold til casen [..]. Og så nogle gange også til ens praksis i hverdagen. Citatet kan tolkes som, at den studerende har fået "øje på sin egen og andres analytiske nuanceringer og differentieringer i forståelsen af praksis" og at "praksis kan belyses, beskrives og forstås gennem en eller flere systematiske teoretiske optikker" (Pjengaard, 2016: 34). I lyset af Pjengaards definition på RPL (se også side 4) er det muligt, at der i denne undersøgelse er identificeret tegn på denne type læring.

De to citater ovenfor peger desuden på, at for de studerende blev refleksionsopgaverne en mulighed for systematisk indsamling af data fra praksis, der efterfølgende kunne analyseres og vurderes i lyset af den 
tilegnede, relevante teori. Refleksionerne blev bindeleddet mellem teori og praksis, og resultatet af refleksionen blev ny erfaring, som bevirkede, at den studerende fik mulighed for at handle i praksis på en anden måde end tidligere. Gennem refleksion fik den studerende mulighed for at skabe distance til den konkrete, praktiske situation, så det blev muligt at analysere denne - og derigennem udvikle metakognitive læringsprocesser. De studerende kunne på denne baggrund udvikle en større forståelse af det teoretiske grundlag og dermed udvikle kompetencer til at undersøge og udfordre egen praksis.

Gennem refleksionsopgaverne fik de studerende således mulighed for at øve sig i at stille spørgsmål til praksis på baggrund af et relevant vidensgrundlag, som en af de studerende fortæller: "[..] for der skal være en problematik, som man virkelig bare mangler at få svar på. Så det er dét, der gør, at man kan bruge det. Det er nogle problemer, jeg har i praksis [..]”. Noget tyder på, at refleksionsopgaverne kan bidrage til udvikling af refleksionskompetencer og dermed mod udvikling af en professionel identitet og professionskompetencer og lægger således op til RPL og udvikling af selvfaciliteringskompetencer.

Refleksive processer lettes, når der er et direkte anvendeligt mål med refleksionen. Det er muligt, at undervisningsforløbets konkrete refleksionsopgaver havde en faciliterende effekt, idet refleksionens genstand, dvs. konkrete forhold fra praksis, direkte blev udpeget for den reflekterende (den diplomstuderende). At der i ovenstående citat gives udtryk for, at refleksionen bruges i praksis, kan derfor tolkes som tegn på, at der er sket en ændring i vedkommendes praksishandlinger. Refleksionen har måske medvirket til transformativ praksislæring; dvs. at læringen har bevirket en ændring i individets adfærd, og i det handlingsforløb det vælger i fremtiden (straightforward transformation (Mezirow, 2000 In. Pjengaard, 2016:19)). Det er dermed muligt, at de konkrete refleksionsopgaver understøtter refleksion over nogle grundlæggende opfattelser af egen læring; dvs. at læringen perspektiveres til tidligere måder at lære/reflektere på. Denne type refleksion definerer Mezirow som kritisk refleksion, idet man her undersøger gyldigheden af et meningsperspektiv, som man har taget for givet. Et eksempel på kritisk refleksion fremgår af nedenstående citat, hvor informanten netop perspektiverer sin aktuelle læring til læring fra tidligere undervisningsforløb.

\footnotetext{
- For mig vil det (læring) sige at man kan bruge det til noget. Nogle gange skulle modulerne bare overstås, det er lidt anderledes den her gang, fordi man har fået det ind under huden på en tvungen måde i forhold til de moduler, jeg ellers har taget. Og det gør en forskel".
} 
Når man møder en udfordring og vælger at tage den op og reflektere over den og derved genskabe balancen, vil det kræve vilje, mod, aktivitet og tænkning (Mezirow, 2000 In: Illeris et al., 2005). Refleksionsopgaverne på diplommodulet udgjorde de udfordringer, der udløste nogle refleksioner af kritisk karaktér. Således har arbejdet med studiets opgaver krævet både vilje, mod, aktivitet og tænkning for den studerende, der fortæller om fordelene ved at arbejde med refleksionsopgaverne: "[..] der skal være en problematik, som man virkelig bare mangler at få svar på. [..] Det er nogle problemer, jeg har i praksis - det er dét, der driver mig, så jeg kan lære noget". Kategorien "Praksisrefleksion" knytter sig derved til kategorien "Forstyrrelse", hvilket uddybes nedenfor.

\section{Forstyrrelse}

I læringssammenhænge forbindes "tvang" sjældent med noget positivt. Alligevel brugte nogle af de PD-studerende begrebet til at beskrive, hvordan de havde oplevet det som nyttigt og lærerigt, at der fra studiets første dag blev forventet af dem, at de løste og "offentliggjorde" refleksionsopgaverne i ePortfolierne. Refleksionsopgaverne er muligvis ikke i sig selv en læringsfremmende faktor i undervisningsdesignet - også kravet om at opgaverne blev løst og kravet om at opgavebesvarelserne blev "offentliggjort" i ePortfolierne har haft en betydning, hviket analyseres nærmere nedenfor.

Schilling et al., (1999 In: Eva, 2013) har vist, at høje forventninger til den enkelte elev spiller positivt ind på elevens muligheder for at præstere. For de PD-studerendes vedkommende var der tale om, at der blev forventet af dem, at de løste konkrete, bundne opgaver, hvor de fx blev bedt om at beskrive særlige situationer fra praksis og efterfølgende koble relevant teori på. De studerende havde med andre ord ikke haft nogen indflydelse på refleksionsopgavernes udforming. Jarvis (1992 In: Illeris, 2000) vil kalde den type opgaver/udfordringer for en other-induced disjuncture, hvilken kun fører til self-directed refleksion og handling - og dermed læring - hvis den lærende opfatter uoverensstemmelsen som meningsfuld og nødvendig. Nedenstående citat indikerer, at refleksionsopgavernes indbyggede udfordringer netop har været både meningsfulde og nødvendige:

\section{- Det er nogle problemer, jeg har i praksis - det er dét, der driver mig, så jeg kan lære noget}

Der er ligeledes i denne undersøgelse fundet tegn på, at konstruerede refleksionsopgaver, der "tvinger" studerende til skriftligt at forholde sig til forholdet mellem studiets teori og egen praksisudførelse kan medføre transformativ og refleksiv læring. 
- [..] Man havde tænkt, at der ikke er nogen test inden for læseforståelse, men det der med at sætte ord på, at vi var tvunget til at sætte ord på - eh, skriftligt, når vi var frustrerede over nogle opgaver, så synes jeg på en eller anden måde, at det hjalp til at forstå, hvad man ikke forstår.

Den studerende fortæller ovenfor, at skriftligheden, dét at sætte ord på frustrationer, hjalp hende/ham til refleksion og en faglig forståelse. Den studerende fortalte gennem skriftlige produkter sig selv, hvad han/hun ikke forstod og fik derved synlig- og tydeliggjort afstanden mellem den nuværende viden og den viden, der var behov for at tilegne sig. De skriftlige produkter skabte indsigt i den studerendes forståelsesprocesser, da han/hun fik mulighed for at lytte til sin egen fortælling. Skriftlige opgavebesvarelser, skriftlige spørgsmål, svar og refleksioner er en permanent form for kommunikation i et asynkront læringsmiljø, og permanent kommunikation kan sidestilles med gentagelser, idet man kan gå tilbage og læse spørgsmål og svar igen og igen; tidsfaktorer trækkes derved ud af læringssituationen og skaber tid og rum for refleksion og faglig fordybelse. Skriftlighed er på denne måde identificeret som værende en læringsfremmende faktor i undervisningsdesignet.

Skriftlige fortællinger forudsætter dog interesserede og kritiske læsere, som gennem tænketaleprocesser bidrager til kvalificering af, i dette tilfælde, den studerendes nye forståelse. En studerende fortalte om dette:
- Der tænker jeg så, at på samme måde kan det jo faktisk også være betryggende at - ok jeg har forstået det på den her måde, og så skriver Monica (underviser), at nej, det er helt hen i vejret, ikke også - og så tænker man, ok, det er nok ikke helt rigtigt læst eller omvendt, ikke også - så får man faktisk bekræftet, at ok, jeg har faktisk forstået det her.

Således knyttes kategorien "Forstyrrelse" til kategorien "Anerkendelse og feedback". Uden anerkendelse og feedback kan usikkerhed og utryghed blokere for, at man gennem skriftlighed får genskabt balancen efter at være blevet "forstyrret" af refleksionsopgavernes krav om at koble problemer i praksis med teori fra pensum. Kategorien "Forstyrrelse" knytter sig dermed også til "Praksisrefleksion".

\section{Anerkendelse og feedback}

Den optimale IT-baserede læringskommunikation finder sted mellem mennesker, der på andre tidspunkter deltager fysisk i læringssammenhænge, idet de vanskeligheder der er identificeret i relation til e-læring ofte er 
forbundet med en følelse af isolation som konsekvens af, at man ikke får umiddelbar respons fra de øvrige deltagere i e-læringsrummene. Dette virker ofte demotiverende (Dohn, 2007). Behov for og nødvendigheden af umiddelbar anerkendelse og feedback udtrykkes af to studerende på denne måde:

- Når man så putter noget ind i ePortfolierne om ens refleksioner $i$ forhold til det, man har læst - hvis det så ikke bliver kommenteret, så har det ikke særlig stor værdi, synes jeg ikke. Men det bliver kommenteret".

- Jeg synes især, det fungerer godt hvis nu Monica (underviser) kommer med sådan nogle overordnede kommentarer, hvor hun så spørger, hvordan jeg vil bruge det her i forhold til min case - så nå ja, så får man lige grejet det sidste. Når der er korrespondance, så virker det bare.

I datamaterialet skelnes mellem underkategorierne anerkendelse og feedback.

Anerkendelse er et bredt begreb, der i denne undersøgelse bruges om dét at fortælle nogen, at man har set og hørt dem og rummer interesse og respekt. Det første af de to ovenstående citater udtrykker behov for og nødvendigheden af anerkendelse; For denne studerende var det ikke så afgørende, om kommentarerne af- eller bekræftede nye forståelser, eller om kommentarerne gav anvisninger til det videre arbejde. For denne studerende var det afgørende, at der var en interesseret læser i den anden ende; at der var nogen at skrive til.

Feedback handler om at få en tilbagemelding på det, man gør, med henblik på at opnå læring omkring, hvad der virker godt, og hvad man kan gøre anderledes. Det andet citat ovenfor udtrykker behov for og nødvendigheden af feedback, hvor kommentarerne ikke blot skal bekræfte læsningen, men desuden være guidende og konstruktive.

Fælles for de to udsagn er, at dét at modtage respons fra underviser og læringsfællesskabets øvrige deltagere var afgørende for de studerendes motivation - og dermed læring, og udfordringen blev for de studerende i denne undersøgelse, at anerkendelse og feedback udelukkende blev formidlet skriftligt og asynkront - og responsen blev stort set kun givet af underviseren. De studerende oplevede derfor både at blive mødt med anerkendende respons og ikke at blive det; således tolkes ovennævnte citater, idet informanterne formår at fastsætte værdien af at få anerkendelse over for dét ikke at få det. At modtage anerkendelse og feedback er identificeret som læringsfremmende faktorer i denne undersøgelse, hvilket står i kontrast til motivationen og viljen 
til at give sine medstuderende anerkendelse og feedback i ePortfolierne, som fortalt af en studerende:

- Det vil for mig være en ekstra opgave at kommentere de andres opslag, men når jeg så ser de andres ... det er rigtigt godt. Det er spændende.

"Anerkendelse og feedback" knytter sig derfor til kategorien "Aktiv/passiv deltagelse".

\section{Aktiv/passiv deltagelse}

Der har været tale om både deltagelse og begrænset deltagelse i de virtuelle refleksionsfællesskaber, som undervisningsforløbet ikke blot stillede til rådighed, men qua konkrete refleksionsopgaver krævede, at man deltog i; dvs. at man både offentliggjorde opgavebesvarelserne, men også refleksioner over teori-praksisforhold i sin ePortfolio. Desuden blev der i studiet lagt op til, at man læste de medstuderendes opgaver og refleksioner og kommenterede på disse.

Læring er en proces, der for mennesket udspiller sig i dets deltagelsesform og interaktion med bl.a. praksisfællesskaber (Wenger, 2004). Praksisfællesskaber er kendetegnet ved at omfatte en række mennesker, der interagerer, handler og lærer i socialt samspil med hinanden og kan, i denne artikels forståelse, også foregå i virtuelle praksisfællesskaber. Et praksisfællesskab indeholder desuden altid tre dimensioner: Gensidigt engagement, fælles virksomhed og repertoire.

\section{- Jeg vil altså sige, at jeg har lært utroligt meget af at kunne simpelthen vade lige ind i de andres opgaver og se, hvad de har skrevet og hvordan de har gjort det og se den feedback, de har fäet. - jeg føler lidt, at jeg også har snuset rundt, men det har virkelig givet mig meget".}

Ikke alle 11 studerende på PD-modulet udviser engagement over for den ePortfolio-praksis, som studiet hviler på. Det gensidige engagement er ikke blot, som citeret ovenfor, at [..] kunne simpelthen vade lige ind i de andres opgaver og se, hvad de har skrevet [..] eller at få inspiration fra de andres opgaver, men det er også at bidrage med noget, som andre kan få inspiration af. Konsekvensen af det manglende engagement i ePortfolio-fællesskabet er, at der ikke er blevet skabt fælles virksomhed som rum for meningsforhandling. Der er ikke noget i datamaterialet, der indikerer, at rammerne for fællesskabet er blevet forhandlet. Data viser derimod tegn på passivitet og tilbagetrækning, som citatet nedenfor indikerer: 
- Jeg ville ikke skrive kommentarer til de andre, fordi jeg ville være $i$ tvivl om, om det er relevante kommentarer, jeg skriver.

Hvis der allerede havde eksisteret et praksisfællesskab, som de studerende kunne have fået indblik i, ville de evt. kunne have set anvendeligheden og meningen med deltagelse. I herværende situation er alle nyankomne på samme tid og mister dermed muligheden for lurking, dvs. dét at kunne stå på sidelinjen og observere. Nye brugere til virtuelle fællesskaber fungerer ofte som lurkers for at lære, hvordan fællesskabet fungerer ved at observere, hvordan erfarne brugere interagerer og opbygger derved det, der kaldes virtuel social kapital (Rafaeli et al., 2004).

Der er imidlertid forskel på fysiske praksisfællesskaber og virtuelle læringsfællesskaber, hvorfor Wengers sociale læringsteori ikke alene kan beskrive den sociale interaktion i FVU-modulets ePortfolier. Dron \& Anderson (2007 In: Dalsgaard \& Paulsen, 2009: 2) beskriver grupper som "individuals who see themselves as part of that group" og uddyber "A group, such as a study group, is a defined collection of individuals who in some way are engaged in joint work". De studerende på FVU-modulet løste imidlertid ikke fælles opgaver; de løste de samme opgaver, men hver for sig.

Virtuelle netværk har en løsere struktur end Wengers praksisfællesskaber. I førstnævnte samarbejder og kommunikerer folk ikke nødvendigvis direkte, hvilket understøttes af den sociokulturelle tilgang, der lægger vægt på problemorienteret og selvstyrende læringsaktiviteter. Dermed vægtes den enkeltes aktivitet, om end disse aktiviteter altid foregår i en social kontekst. I FVU-undervisningsforløbet var den sociale kontekst, qua ePortfolierne, gennemsigtig, hvorfor der blev skabt mulighed for, at studerende og undervisere blev opmærksomme på - og havde adgang til - hinandens refleksioner og opgavebesvarelser. De studerende og underviserne stod dermed til rådighed for hinanden som ressourcer for deres læringsaktiviteter; det gennemsigtige læringsmiljø blev dén sociale kontekst, hvor de studerende hentede både forstyrrelser - i form af nuanceringer, inspiration og refleksionsopgaver - og anerkendelse og feedback i form af primært underviserens respons. Citatet nedenfor opsummerer dette:

\section{- Jeg vil altså sige, atjeg har lært utroligt meget af at kunne simpelthen vade lige ind i de andres opgaver og se, hvad de har skrevet og hvordan de har gjort det og se den feedback, de har fået}

Kategorien "Aktiv/passiv deltagelse" knyttes derfor til "Forstyrrelse" og "Anerkendelse og feedback". 


\section{Konklusion}

Procesteorien (figur 2) er funderet i det empiriske materiale og er udviklet på baggrund af forskningspørgsmålet "hvilke faktorer opleves som læringsfremmende hos den enkelte studerende, når undervisningsforløbet er tilrettelagt som BL og med ePortfolier som omdrejningspunkt for social læring og refleksion, og kan den læring der sker, identificeres som refleksiv praksislæring"? Procesteorien opsummeres og diskuteres nedenfor.

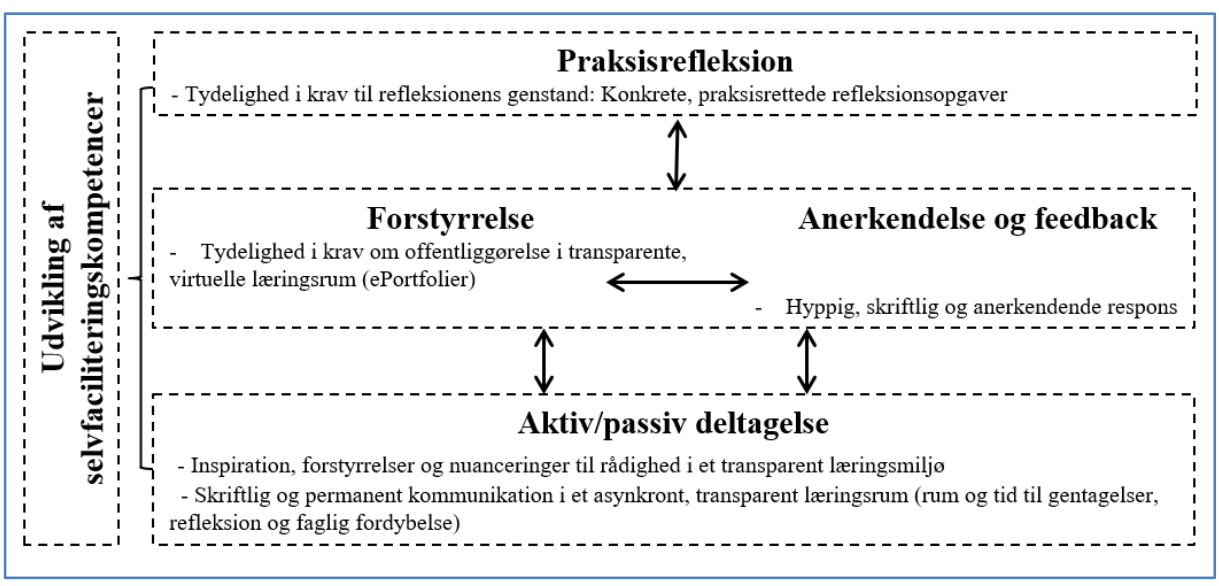

Figur 2. Undersøgelsens procesteori med angivelse af læringsfremmende faktorer i et undervisningsforløb tilrettelagt som blended learning og med inddragelse af ePortfolier.

Der blev i denne undersøgelse fundet tegn på læring af transformativ karakter som følge af kritisk og målrettet refleksion. Behovet og motivationen for refleksion og læring kan udløses af konkrete og praksisrettede refleksionsopgaver, hvortil var knyttet en forventning om, at de blev løst og offentliggjort i de PD-studerendes individuelle, men transparente ePortfolier. Der fandt refleksion og læring sted, fordi opgaverne blev fundet meningsfulde og nødvendige, og fordi refleksionens genstand (en problemstilling i praksis) blev angivet i opgavebeskrivelserne. Refleksionsopgaverne blev derved medspillere i et læringsmiljø, hvorfra de studerende kunne hente inspiration, forstyrrelser og nuanceringer til brug i det individuelle kritiske refleksionsarbejde.

En tæt, virtuel kontakt med hyppig, skriftlig og anerkendende respons er en forudsætning for læring for en PD-studerende i et undervisningforløb tilrettelagt som blended learning. Når kontakten er tilstrækkelig, skabes den tryghed, der er nødvendig for udnyttelse af et asynkront læringsmiljø med permanent kommunikation; et sådant læringsmiljø skaber mulighed for refleksion og faglig fordybelse. Således er der identificeret tegn på ændring i praksishandlinger som følge af refleksion og læring. 
Resultaterne pegede også på, at der har været tale om både deltagelse, begrænset deltagelse og ikke-deltagelse i ePortfolierne, som udgjorde de virtuelle refleksions- og læringsfællesskaber. FVU-modulet var ikke et praksisfællesskab som beskrevet af Wenger, men de studerende havde alligevel fundet det lærerigt og inspirerende at læse hinandens opgaver og refleksioner. I et e-læringsfællesskab er det den enkeltes aktivitet - og den enkeltes bevidsthed om de andres aktiviteter, der er afgørende for læringen. Desuden blev det gennemsigtige læringsmiljø dén sociale kontekst, hvor de studerende hentede både forstyrrelser, nuanceringer, anerkendelse og feedback. I den forbindelse viste Dohns (2007) undersøgelser, at IT-mediet er uforpligtende og vanskeliggør "ansvar for egen læring", fordi man uden konsekvenser kan undlade at deltage. Et resultat fra denne undersøgelse viser imidlertid, at deltagelse og ikke-deltagelse i højere grad handler om studiets indhold og form end om IT-mediet.

Tydelighed i krav til skriftlige opgaver og tydelighed i krav om deltagelse samt et anerkendende, inspirerende og transparent virtuelt læringsmiljø viste sig i denne undersøgelse at bidrage til udvikling af PD-studerendes refleksionskompetencer.

Procesteorien bidrager således til en samlet forståelse af læringsfremmende, didaktiske designs i relation til undervisningsforløb tilrettelagt som blended learning, hvori inddrages ePortfolier og kan danne baggrund for den videre udvikling på området.

Undersøgelsens resultater peger på, at de tegn på læring, der er identificeret, placerer sig i sociale, praksisrettede og refleksive læringsdimensioner og dermed kan være tegn på RPL. Disse resultater understøttes af, at de PDstuderende på FVU-modulet opnåede de fleste af de opsatte mål for RPL.

RPL er en kompleks og selvstændig måde "at lære at lære på", der udvikler og former den enkeltes professionelle identitet og professionskompetencer. RPL er dermed et led i udvikling af selvfaciliteringskompetencer, hvor den diplomstuderende aktivt deltager i egen læreproces; dvs. at læringen initieres, kontrolleres og styres af den studerende i en livslang og iterativ proces.

Selvfaciliterende professionelle sikrer en kontinuerlig udvikling af praksis gennem deres handlinger og kommunikation; dvs. de anvender deres teoretiske viden til at løse problemer i praksis. Et læringsdesign der sigter mod professionalitet bør derfor sikre udviklingen af professionel identitet og dømmekraft gennem teoretisk og forskningsbaseret indsigt koblet med evnen til at udvikle praksis via refleksion. 
Det vurderes, at læringsdesignet i denne undersøgelse har bidraget til formning af en professionel identitet og professionskompetencer hos de studerende, der deltog i undervisningsforløbet.

\section{Referencer}

Bjerresgaard, H. \& Hermansen, M. (2016). Undervisning mellem håndværk og kunst. Samfundslitteratur, Viborg

Bollinger, D.U. \& Shepherd, C.E. (2010). Student perceptions of eportfolio integration in online courses. Distance Education, 31(3), 295-314.

Boud, Cohen \& Sampson (1999). Peer learning and assessment. Assessment and Evaluation in Higher Education, 24, 4, 413-426

Dalsgaard, C. (2011). Personlige læringsmiljøer: Universitetsuddannelse på internettet. Dansk Universitetspædagogisk Tidsskrift, nr. 11, 2011

Dalsgaard, C. \& Paulsen, M. F. (2009). Transparency in Cooperative Online Education. The International Review of Research in Open and Distance Learning, 10(3).

Dau, S. (2015). Studerendes orientering i fleksible professionsuddannelsers læringsrum. Et narrativt casestudie af vidensudviklingens veje og afveje. Ph.d.-afhandling. Aalborg University

Dohn, N. B. (2007). IT-baserede læreprocesser - nogle muligheder og nogle begrænsninger. Dansk Universitetspædagogisk Tidsskrift nr. 4, 2007

Danmarks Evalueringsinstitut (2011). "E-læring og blended learning på VEUområdet".

Dysthe, O. (2003). Dialog samspil og læring. Forlaget Klim, Århus

Dysthe \& Engelsen (red.) (2005). Mapper som pædagogisk redskab. Perspektiver og erfaringer. Forlaget Klim, Århus

Ellmin, R. (2001). Portfoliomodellen - en måde at lære og tænke på. Gyldendal Uddannelse

Glaser, B. G. \& Strauss, A. L. (1967). The Discovery of Grounded Theory. Aldine Transaction. A Division of Transaction Publishers. New Brunswick (U.S.A.) and London (U.K.). Reprinted 2006

Graham, C. R. (2013). Emerging practice and research in blended learning. Handbook of distance education, 3. 
Hartman, J. (2005). Funderet teori. Udvikling af teori på empirisk grundlag. København: Alinea.

Hermansen, M. (2003). Omlæring. Forlaget Klim. Århus

Illeris, K. (2007). Læring. Roskilde Universitetsforlag

Jarvis, Peter (1992): Den menneskelige lærings natur, in: Illeris, Knud (Red.); 2000, Tekster om læring, 1. udgave, Roskilde Universitetsforlag, Gylling.

Jones, S. A., Downs, E. \& Jenkins, S. J. (2015). Transparency in the ePortfolio Creation Process. Association for Educational Communications and Technology, 2015

Knoop, H. H. til Rasmussen, M. Så anerkend mig dog! In: Kristeligt Dagblad, 15.09.2016

Lowenthal, P.R., \& Thomas, D. (2010). Death to the digital dropbox: Rethinking student privacy and public performance. EDUCAUSE Quarterly, 33(3).

Lund, B. (2008). Portfolio i et lærings- og uddannelsesperspektiv. Aalborg Universitetsforlag

Mezirow, Jack (2000): At lære at tænke som en voksen, in: Illeris, Knud og Berri, Signe (Red.); 2005, Tekster om voksenlæring, 1. udgave, Roskilde Universitetsforlag, Gylling.

Pjengaard, S. (2016). Refleksiv praksislæring i relation til den klassiske læringspsykologi. Del l, ll, lll. Tidsskrift for evaluering i praksis. Ceprastriben, nr. 20 (2016). Center for evaluering i praksis, CEPRA, UCN (p. 10 35)

Rafaeli, S., Ravid, G., \& Soroka, V. (2004). De-Lurking in Virtual Communities: A Social Communication Network Approach to Measuring the Effects of Social and Cultural Capital. In R.H. Sprague (Chair), Proceedings of the 37th Annual Hawaii International Conference on System Sciences (HICSS 04) (p. 10). Los Alamitos, CA: IEEE.

Schilling, K. and Schilling, L. (1999). Increasing expectations for student effort. In: About Campus, 4:2. In: Danmarks Evalueringsinstitut (2013). Høje forventninger til alle elever

Strauss, A., \& Corbin, J. (1998). Basics of Qualitative Research - Techniques and Procedures for Developing Grounded Theory. Thousand Oaks, California: SAGE Publications Ltd. 
Sorensen, E. K. (2000). Interaktion og læring i virtuelle rum. I S. Heilesen (red.), Universiteter i Udvikling - IKT og Undervisning. Samfundslitteratur, København

Torrisi, R. G., \& Drew, S. (2014). The literature landscape of blended learning in higher education: the need for better understanding of academic blended practice. Lokaliseret d. 28. januar 2018 på:

http://www98.griffith.edu.au/dspace/bitstream/handle/10072/52652/8 6644_1.pdf?se quence=1

Wenger, E. (2004). Praksisfællesskaber. Hans Reitzel, København

E-portfolio | Knowledge Lab: http://knowledgelab.dk/projekter/eportfolio.html 